\title{
Anaokuluna Devam Eden 66 Ayını Doldurmuş Çocukların Öz Düzenleme Becerileri İle Akran İlişkileri Arasındaki İlişkinin İncelenmesi
}

\section{Hüray Pazarbaşı ${ }^{1 *}$ \\ Prof. Dr. Kadriye Esin Cantez ${ }^{2}$}

Geliş tarihi: 25.09.2019

Kabul tarihi: 28.10.2019

\section{Atıf bilgisi: \\ IBAD Sosyal Bilimler Dergisi \\ Sayl: $5 \quad$ Sayfa: $267-283$ \\ Yıl: 2019 Dönem: Güz}

This article was checked by Turnitin. Similarity Index 27\%

1 İstanbul Aydın Üniveritesi, Türkiye, huraypazarbasi@gmail.com ORCID ID 0000-0002-4559-4944

2 İstanbul Kent Üniversitesi, Türkiye, esin.cantez@kent.edu.tr

ORCID ID 0000-0000-0000-0000

* Sorumlu yazar öz

Araştırmada öz düzenleme becerileri ile akran ilişkileri arasındaki ilişkileri belirlemek amaçlanmıştır. Araştırmaya Ankara ilinde bir özel anaokuluna devam eden 66 ayını doldurmuş 56 çocuk katılmıştır. Çocukların öz düzenleme becerilerini ölçmek için Okul Öncesi Öz Düzenleme Ölçeği, akran ilişkilerini ölçmek için ise Ladd ve Profilet Çocuk Davranış Ölçeği kullanılmıştır. Nicel model kullanılan araștırmada betimsel analiz yapılmıs ve ilișkisel tarama deseni kullanılmıștır. Verilerin analizinde SPSS 25.0 istatistik paket programı kullanılmış ve verilerin değerlendirmesinde frekans analizi, Pearson Korelasyon analizi, oneway anova testi, t-testi uygulanmıștırAraştırmada, öz düzenleme becerileri ile akran ilişkileri arasında bazı yönlerden anlamlı ilişkilere rastlanmıştır. Araştırma sonuçlarına göre akranlarına karşı yardımı amaçlayan sosyal davranış gösterme puanı arttıkça dikkat puanı, davranış düzenleme puanı ve sosyallik puanının arttığı, aşırı hareketlilik puanı arttıkça dikkat puanının azaldığı, saldırganlık puanı arttıkça dikkat puanının azaldığı, dışlanmışlık puanı arttıkça dikkat puanının ve davranış düzenleme puanının azaldığı belirlenmiștir.

Anahtar Kelimeler: Sosyal Gelişim, Öz Düzenleme, Akran İlişkileri. 
The Relationship between Self-Regulation Skills and Peer Relations among 66 MonthsOld Children Attending Kindergarten

Hüray Pazarbaşı ${ }^{1 *}$

Prof. Dr. Kadriye Esin Cantez ${ }^{2}$

First received: 25.09 .2019

Accepted: 28.10 .2019

\section{Citation:}

IBAD Journal of Social Sciences

Issue: $5 \quad$ Pages: 267-283

Year: $2019 \quad$ Session: Fall

This article was checked by Turnitin. Similarity Index 27\%

1 İstanbul Aydın Universitiy, Turkey, huraysaracoglu@gmail.com,

ORCID ID 0000-0002-4559-4944

2 İstanbul Kent Universitiy, Turkey, esin.cantez@kent.edu.tr ORCID ID 0000-0000-0000-0000

\footnotetext{
* Corresponding Author
}

\begin{abstract}
The purpose of the study is to determine the relationships between children's selfregulation skills and peer relationships is examined. 56 children who are 66 months old, attending a special kindergarten in Ankara province participated in this study. Preschool Self-Regulation Scale was used to measure self-regulation skills of the children and Ladd and Profilet Child Behavior Scale was used to measure peer relationships. 'Descriptive analysis' was performed and 'relational screening model' was used in the research developed by qualitative model. SPSS 25.0 statistical package program was used to analyze the data. Frequency analysis, Pearson Correlation analysis, one-way ANOVA test and t-test were used to evaluate the data. There are several significant relationships between children's self-regulation skills and peer relationships were found in this study: As the score of prosocial behaviors increase among the self-regulation and peer relations; the attention score, behavior regulation score and sociability score increase. The attention score decreases as the hyperactivity score increases. The attention score decreases as the aggression score increases, and the attention score and behavior regulation score decrease, as the exclusion score increases.
\end{abstract}

Keywords: Social Development, Self-Regulation, Peer Relationships. 


\section{GíRIŞ}

Sosyal beceriler, iletişim kurmaya, problemlerle baş edebilmeye, karar vermeye, kendini yönetmeye, diğer bireylerle sağliklı sosyal ilişkilere temel oluşturmaya ve devam ettirmeye izin veren becerilerdir. Bireyler, içinde bulunduğu toplumun kurallarını ve gereklerini öğrenerek; yaşadığı kültürde bulunan insanlara uyum sağlarken, gruba dahil olmak için temel alışkanlıkları kazanır, gereken değerleri ve davranışları öğrenirler (Gander ve Gardiner, 1998, s. 82).

Öz düzenleme, bireyin bilişsel, motivasyonel ve davranışsal olarak öğrenme sürecini kontrol etmesi anlamına gelmektedir (Zimmerman, 2000; Aktaran: Erol ve İvrendi, 2018, s. 178). Öz düzenleme ile ilgili farklı tanımlar mevcuttur. "Öz düzenleme genel olarak bireyin düşüncelerini, duygularını, dürtülerini, dikkatini ve davranışlarını kontrol etmesi ve düzenlemesi olarak tanımlanmaktadır." (Ahioğlu, 2008, s. 163). Bir isteği yerine getirme, bir işi başlatabilme ve sonlandırabilme, davranışlarının sıklığını, süresini ve yoğunluğunu ayarlayabilme, isteklerini erteleyebilme, başkaları olmadığında da olumlu sosyal davranışlar sergileme becerisidir (Kopp, 1982; Aktaran: Erol ve İvrendi, 2018, s. 178).

Öz düzenlemenin gelişimi doğumdan başlayarak, erken çocukluğun sonuna kadar önemli ilerlemeler göstererek gelişmektedir (McCabe, Cunnington ve Brooks-Gunn, 2004, s. 213). Bu süreç içerisinde öz düzenlemenin dört yaştan sonra gözlemlenebilecek boyuta ulaşmakla birlikte gelişimi devam etmektedir (Posner ve Rohtbart, 2000, s. 103).

Vygotsky'e göre oyun, çocukların yönergeye uymalarını değil, kendi kurallarını koyarak, sınırları kendilerinin oluşturmalarını sağlar. Çocuğun, kendini tanıyarak davranışlarını kontrol ettiği (Huizinga, 1995; Aktaran: Aksoy ve Tozduman, 2017), kendi oyun kullarını koymayla başladığı bu süreçte öz düzenlemenin de başladığı düşünülmektedir (Bodrova, Germeroth ve Leong, 2013, s. 118).

Sağlıklı ve başarılı ilişkiler, bireyin erken çocukluk döneminde akranlarıyla kurdukları iletişim ile başlar. Akran etkileşimlerinin sosyalleşmeyi hızlandırıcı etkisi de bulunmaktadır. Çocuklar akranlarıyla etkileşime geçerek, içinde bulunduğu toplumun değer yargılarını, bu değerlere uymayı ve öz farkındalığını geliştirmeyi öğrenir. Yaşamın ilk yıllarında kurulan akran ilişkileri, bireyin sosyal, duygusal, bilişsel, dil, psikomotor alanlarında geniş ve iz bırakıcı etkilere neden olmaktadır (Gülay, 2010, s. 732).

Okullarda başarısız akran ilişkilerini kurulmasıyla çeşitli sorunlu davranışlar ortaya çıkabilmektedir. Bu sorunlu davranışlar, bireyin sonraki yaşantısında farklı problemlere yol açabilmektedir (Gülay ve Akman, 2009, s. 207). Arkadaş edinmeyen çocukların, daha az olumlu sosyal davranış sergilediklerini Wentzel, McNamara-Barry ve Caldwell (2004) yaptıkları araştırmalar sonucu ortaya çıkarmışlardır.

Doll, Murphy ve Song (2003)'a göre akranlarının çocuğa destek vermesi, çocuğun stresli durumlarla baş etmesini, akran zorbalığından korunmasını sağlar. Akademik motivasyonun ve akademik başarının önemli bir unsurudur. Akranlarla ilişkiler, sosyal ortamlara uyum sağlamada, çocukların yakın ilişkiler geliştirmelerini sağlamada katkı sağlarken çocuğun artan arkadaş sayısıyla sosyal uyumunu kolaylaştırmaktadır.

Huh ve diğerleri (2003)'ne göre çocukların sorunlu davranışlar göstermeleri ile akranları tarafindan kabul edilmeleri arasında tutarlı bir ilişki vardır. Öz düzenlemenin, olumlu sosyal davranışlar sergileme becerisi olduğu bilgisinden yola çıkarak, öz düzenleme becerileri gelişmiş çocukların, akran ilişkileri kurmada daha başarılı olacağı, çocukların akran ilişkilerini geliştirebilmek için öz düzenleme becerilerinin desteklenmesi gerektiği düşünülmektedir. Okul Öncesi Öz Düzenleme Ölçeği, Ladd ve Profilet Çocuk Davranış Ölçeği sonucu 66 ayını doldurmuş çocukların çoğunlukla düşük puan aldıkları beceriler saptanarak geliştirilmesi gereken yönlerin belirlenmesi ile belirlenen öz düzenleme becerilerinin geliştirilmesi, bu doğrultuda olumlu akran ilişkilerinin desteklenmesi hedeflenmiştir. $\mathrm{Bu}$ çalışma, Türkiye'de henüz yeterli araştırma bulunmayan okul öncesi öz düzenleme çalışmalarına ve akran ilişkileri ile ilgili çalışmalara kaynak olacaktır. 


\section{YÖNTEM}

\section{Araştırmanın Modeli}

$\mathrm{Bu}$ çalışma anaokuluna devam eden 66 ayını doldurmuş çocukların öz düzenleme becerileri ile akran ilişkileri arasındaki ilişkinin incelenmesine yönelik tarama modellerinden ilişkisel modelde gerçekleştirilmiş bir çalışmadır. İlişkisel tarama modeli, birden fazla sayıdaki değişkenlerde birlikte değişimini ya da derecesini belirlemede kullanılır (Karasar, 2005, s. 82).

\section{Çalışma Grubu}

Bu araştırmada ele alınan örneklem grubunu 27 kız (\% 48.2), 29 erkek (\% 51.8) olmak üzere 56 çocuk oluşturmuştur. Araştırmada çalışma grubu olarak Ankara ilinde bulunan bir özel okulun anasınıfı öğrencilerinden, 66 ayını doldurmuş çocuklar seçilmiştir.

\section{Veri Toplama Araçları}

Okul öncesi dönem çocuklarının kendilerini düzenleme becerilerini ölçümlemek ve akran ilişkilerini saptamak için iki ölçek kullanılmıştır.

Okul Öncesi Öz Düzenleme Ölçeği: Smith-Donald ve arkadaşları (2007)'nın geliştirdiği okul öncesi dönem çocuklarının kendilerini düzenleme becerilerini ölçümleyebilmek için "Okul Öncesi Öz Düzenleme Ölçeği" kullanılmıştır. Belirtilen ölçekte bulunan uygulayıcı değerlendirme formu, çalışmacıya, çocuğun duygu düzenlemesi, dikkat seviyesi ve davranış kontrolünü, uygulayıcının çocuk ile etkileşime girerek gözlemlemesine imkan tanır. Form, 0 ile 3 arası puan verilerek değerlendirilen maddelerden oluşur. 16 maddeden oluşan ölçek, geçerlilik kapsamında yapılan faktör analizi neticesinde ölçeğin Dikkat/Dürtü Kontrolü ve Olumlu Duygu faktörlü bir yapıda olduğu belirlenmiştir (Fındık Tanrıbuyurdu ve Güler Yıldız, 2014, s. 176).

Ölçeğin tamamını oluşturan 16 maddeye ilişkin güvenirlik katsayısı $(\alpha) .83$ olarak belirlenmiştir. Ölçeğin Dikkat/Dürtü Kontrolü faktörünün 10 maddeye ilişkin güvenirlik katsayıs1 .88, ikinci faktör olan Olumlu Duygu için ise güvenirlik katsayıs1 80 olarak belirlenmiştir. 'Okul Öncesi Öz Düzenleme Ölçeği'ne ait 10 farklı görev bulunmaktadır. Bu görevler sırasıyla; düz çizgi üzerinde yürüme, kalem tıklatma, küpleri üst üste dizme, küpleri toplama, nesneleri gruplandırma, nesneleri toplama, hediye paketini açma, oyuncağı geri verme, yönergeyi bekleme, şekeri ağzında tutma şeklindedir (Fındık Tanrıbuyurdu ve Güler Y1ldız, 2014, s. 176).

Ladd ve Profilet Çocuk Davranış Ölçeği: 1996' da öğretmenlerin bilgileri doğrultusunda, okul öncesi dönem çocuklarının okulda akranlarıyla olan ilişkilerini değerlendirmek amacıyla, Ladd ve Profilet tarafından geliştirilmiş bir ölçme aracıdır. Ölçek, akran ilişkilerini etkileyen saldırgan davranış, başkalarına yardımı amaçlayan sosyal davranış, asosyal davranış, dışlanma, korkulu-kaygılı olma ve aşırı hareketlilik olmak üzere çeşitli değişkenleri temsil eden 6 alt ölçekten oluşmaktadır (Ladd ve Profilet, 1996, s. 1010). Ölçekteki tüm maddeler "Uygun Değil", "Bazen Uygun", "Tamamen Uygun" ifadeleriyle değerlendirilmektedir. Ölçekte, alt ölçeklerin yapısı gereği genel bir toplam puandan söz edilememektir. Her bir alt ölçek, kendi içinde değerlendirilmektedir. Alt ölçeklerden alınan toplam puanlar, o ölçeğin temsil ettiği davranışın hangi sıklıkta gerçekleştirildiğini ifade etmektedir. Ölçek, Gülay (2008) tarafından Türkçeye uyarlanmıştır. Dilsel eşdeğerlik çalışmasının ardından yapılan güvenirlik geçerlik çalışmaları sonucunda, ölçeğin iç tutarlık katsayısı .81 olarak belirlenmiştir. Akranlarına karsı saldırganlık alt ölçeğinin iç tutarlık katsayısı .87, akranlarına karsı yardımı amaçlayan sosyal davranışlar göstermek alt ölçeğinin iç tutarlık katsayısı .88, akranlarına karsı asosyal davranışlar göstermek alt ölçeğinin iç tutarlık katsayısı .84, akranlarına karsı korkulu-kaygılı olma alt ölçeğinin iç tutarlık katsayısı .78, akranları tarafindan dışlanma alt ölçeğinin iç tutarlık katsayısı .89, aşırı hareketlilik alt ölçeğinin iç tutarlık katsayısı .83 olarak belirlenmiştir (Gülay, 2008, s. 729).

Kişisel Bilgi Formu: Bu form çocukların sosyo-demografik özelliklerini saptamak için kullanılmıştır. Cinsiyet, yaş, kardeş sayısı, aile eğitim durumu ile ilgili maddelerden oluşmaktadır. 


\section{Verilerin Analizi}

Çalışmadan toplanan veriler yorumlanırken, SPSS (Statistical Package for Social Sciences) 25.0 programı kullanılmıştır. Çalışma bulguları yorumlanırken yüzde, standart sapma vb. istatistiksel metotlar kullanılmıştır. Araştırmaya katılan çocukların "Ladd ve Profilet Çocuk Davranış Ölçeği”" ve "Okul Öncesi Öz Düzenleme Ölçeği” sonucu elde edilen puanların; annenin eğitim durumu, annenin yaşı, babanın eğitim durumu, babanın yaşı, cinsiyet, kardeş sayısı ve kardeşlerin cinsiyetine göre farklılık gösterip göstermedikleri incelenmiştir. Cinsiyet, annenin eğitim durumu, annenin yaşı, babanın eğitim durumu, babanın yaşı, kardeş sayısı ve kardeşlerin cinsiyetine akran ilişkileri üzerine etkisini görmek amacıyla t Testi, Tukey Testi, ANOVA ve Pearson korelasyonu yöntem olarak kullanılmıştır. Aynı zamanda araştırmada, aritmetik ortalama ve standart sapmaların hesaplanması için betimsel istatistik tercih edilmiştir.

\section{BULGULAR}

\section{Demografik Özellikler ile İlgili Bulgular}

Tablo 1: Cinsiyetlere Göre Dağılım

\begin{tabular}{lcc}
\hline \hline & Frekans & Yüzde \\
\hline Kiz & 27 & 48,2 \\
Erkek & 29 & 51,8 \\
Toplam & 56 & 100,0 \\
\hline
\end{tabular}

Cinsiyetlere göre dağılım Tablo 1'de incelenmiştir. Araştırmada yer alan çocukların 27'si (\% 48,2) kız, 29 'u $(\%$ 51,8) erkektir.

Tablo 2: Anne Eğitim Durumuna Göre Dağılım

\begin{tabular}{lcc}
\hline \hline & Frekans & Yüzde \\
\hline Lise Mezunu & 6 & 10,7 \\
Üniversite mezunu & 50 & 89,3 \\
Toplam & 56 & 100,0 \\
\hline
\end{tabular}

Anne eğitim durumuna göre dağllım tablo 2 'de incelenmiştir. Araştırmada yer alanlardan 6 'sının (\% 10,7) annesinin lise mezunu, 50'sinin (\% 89,3) annesinin üniversite mezunu olduğu saptanmıştır.

Tablo 3: Baba Eğitim Durumuna Göre Dağılımı

\begin{tabular}{lcc}
\hline \hline & Frekans & Yüzde \\
\hline Lise mezunu & 8 & 14,3 \\
Üniversite mezunu & 48 & 85,7 \\
Toplam & 56 & 100,0 \\
\hline
\end{tabular}

Baba eğitim durumuna göre dağılım tablo 3 'te belirtilmiştir. Araştırmada yer alan çocukların 8'inin (\% $14,3)$ babasının lise mezunu, 48 'inin (\% 85,7) babasının üniversite mezunu olduğu saptanmıştır.

Tablo 4: Annelerinin Yaş Grubuna Göre Dağılımı

\begin{tabular}{lcc}
\hline \hline & Frekans & Yüzde \\
\hline $20-30$ yaş aras1 & 4 & 7,1 \\
$31-40$ yaş arası & 38 & 67,9 \\
41 yaş ve üstü & 14 & 25,0 \\
Toplam & 56 & 100,0 \\
\hline
\end{tabular}

Tablo 4'e göre araştırmada yer alan çocukların 4'ünün (\% 7,1) annesinin 20-30 yaş aralığında, 38'inin $(\%$ 67,9) annesinin 31-40 yaş aralığında, 14 'ünün $(\% 25,0)$ annesinin 41 yaş ve üstü olduğu saptanmıştır. 
Tablo 5: Babalarının Yaşlarına Göre Dağılımı

\begin{tabular}{lcc}
\hline \hline & Frekans & Yüzde \\
\hline $31-40$ yaş arası & 40 & 71,4 \\
41 yaş ve üstü & 16 & 28,6 \\
Toplam & 56 & 100,0 \\
\hline
\end{tabular}

Babaların yaş dağılımı tablo 5'te belirtilmiştir. Araştırmada yer alan çocuklardan 40'1nın $(\% \mathbf{7 1 , 4 )}$ babasının 31-40 yaş aralığında, 16'sının $(\%$ 28,6) babasının 41 yaş ve üstü olduğu belirlenmiştir.

Tablo 6: Kardeș Sayısına Göre Dağılımı

\begin{tabular}{lcc}
\hline \hline & Frekans & Yüzde \\
\hline Kardeşi yok & 34 & 60,7 \\
1 kardeşi var & 17 & 30,4 \\
kardeşi var & 5 & 8,9 \\
Toplam & 56 & 100,0 \\
\hline
\end{tabular}

Tablo 6 baz alındığında araştırmada yer alan çocuklardan 34’ünün (\% 60,7) kardeş sahibi olmadığı, 17 'sinin $(\% 30,4)$ bir kardeş sahibi olduğu, 5 'inin $(\%$ 8,9) üç kardeş sahibi olduğu belirlenmiştir.

Tablo 7: Kardeş Cinsiyetine Göre Dağılımı

\begin{tabular}{lcc}
\hline \hline & Frekans & Yüzde \\
\hline Kiz kardeşi var & 9 & 16,1 \\
Erkek kardeşi var & 8 & 14,3 \\
Hem kız hem erkek kardeşi var & 5 & 8,9 \\
Kardeşi yok & 34 & 60,7 \\
Toplam & 56 & 100,0 \\
\hline
\end{tabular}

Tablo 7 ele alındığında araştırmada yer alan çocuklardan 9'unun (\%16,1) kız kardeş sahibi olduğu, 8 'inin $(\%$ 14,3) erkek kardeş sahibi olduğu, 5'inin $(\% 8,9)$ hem erkek hem kız kardeş sahibi olduğu 34 'ünün $(60,7)$ kardeş sahibi olmadığı saptanmıştır.

Tablo 8: Araştırmada Yer Alan Çocukların Akran İlişki Düzeylerinin Cinsiyet Değişkenine Göre Farklılaşması

\begin{tabular}{|c|c|c|c|c|c|}
\hline Cinsiyet & & $\mathbf{N}$ & Mean & Std. Deviation & $\mathbf{P}$ \\
\hline \multirow[t]{2}{*}{ Hiperaktivite_Ort } & $\mathrm{K}_{1 \mathrm{Z}}$ & 27 & 1,4352 & 0,49804 & 0,085 \\
\hline & Erkek & 29 & 1,7241 & 0,65922 & \\
\hline \multirow[t]{2}{*}{ Saldırganlık_Ort } & K1Z & 27 & 1,3704 & 0,47257 & 0,112 \\
\hline & Erkek & 29 & 1,4975 & 0,63616 & \\
\hline \multirow[t]{2}{*}{ Dişlanmış_Ort } & $\mathrm{K}_{1 \mathrm{Z}}$ & 27 & 1,1481 & 0,24579 & 0,004 \\
\hline & Erkek & 29 & 1,3153 & 0,50850 & \\
\hline \multirow[t]{2}{*}{ Kayg1_Korku_Ort } & $\mathrm{K}_{1 \mathrm{Z}}$ & 27 & 1,4815 & 0,24265 & 0,064 \\
\hline & Erkek & 29 & 1,5287 & 0,37168 & \\
\hline \multirow[t]{2}{*}{ Asosyal_Ort } & $\mathrm{K}_{1 \mathrm{Z}}$ & 27 & 1,2963 & 0,42844 & 0,581 \\
\hline & Erkek & 29 & 1,3645 & 0,49573 & \\
\hline \multirow[t]{2}{*}{ Prososyal_Ort } & K1Z & 27 & 2,7111 & 0,31663 & 0,000 \\
\hline & Erkek & 29 & 2,4621 & 0,47840 & \\
\hline
\end{tabular}

Araştırmaya katılan çocukların dışlanma puanları ortalamalarının cinsiyet değişkenine göre anlamlı bir farklılık gösterip göstermediğini belirlemek amacıyla yapılan $\mathrm{t}$ testi sonucunda grup ortalamaları arasındaki fark istatistiksel açıdan anlamlı bulunmuştur $(\mathrm{p}=0,004<0,05)$. Ortalamalar arasındaki farka göre, erkek çocukların dişlanmışlık puanları ( $\mathrm{x}=1,3153)$, kı çocukların dışlanma puanlarından $(\mathrm{x}=1,1481)$ yüksektir.

Araştırmaya katılan çocukların akranlarına karşı yardımı amaçlayan sosyal davranış gösterme puanları ortalamalarının cinsiyet değişkenine göre anlamlı bir farklılık gösterip göstermediğini belirlemek amacıyla yapılan $\mathrm{t}$ testi sonucunda grup ortalamaları arasındaki fark istatistiksel açıdan anlamlı bulunmuştur $(\mathrm{p}=0,000<0,05)$. Ortalamalar arasındaki farka göre, kız çocukların akranlarına karşı yardımı 
amaçlayan sosyal davranış gösterme puanları $(\mathrm{x}=2,7111)$, erkek çocukların akranlarına karşı yardımı amaçlayan sosyal davranış gösterme puanlarından $(x=2,4621)$ yüksektir. Araştırmaya katılan çocukların akranlarına karşı asosyal davranış geliştirme puanları ortalamalarının cinsiyet değişkenine göre anlamlı bir farklılık gösterip göstermediğini belirlemek amacıyla yapılan $t$ testi sonucunda grup ortalamaları arasındaki fark istatistiksel açıdan anlamlı bulunmamıştır $(\mathrm{p}=0,581>0,05)$.

Araştırmada yer alan çocukların akranlarına yönelik korku-kaygı duyma puan ortalamalarının cinsiyet değişkeni ele alındığında anlamlı bir ilişki olup olmadığını anlamak sebebiyle yapılmış olan $t$ testinin sonuçlarında grup ortalamaları arasındaki fark istatistiksel açıdan anlamlı bulunmamıştır $(\mathrm{p}=0,064>0,05)$. Araştırmada yer alan çocuklardan saldırganlık puanları ortalamalanın cinsiyet değişkenine göre anlamlı bir değişkenlik gösterip göstermediğini anlamak sebebiyle yapılan $t$ testinin sonuçlarında grup ortalamaları arasındaki değişim istatistiksel açıdan anlamlı bulunmamıştır $(\mathrm{p}=0,112>0,05)$. Araştırmada yer alan çocuklardan aşırı hareketlilik puanları ortalamanın cinsiyet değişkenine göre anlamlı bir değişken gösterip göstermediğini anlamak sebebiyle gerçekleștirilen $t$ testinin sonunda grup ortalamaları arasındaki değişim istatistiksel açıdan anlamlı bulunmamışırı $(\mathrm{p}=0,085>0,05)$.

Tablo 9: Araştırmada Yer Alan Çocukların Akran İlişski Düzeylerinin Anne Eğitim Durumu Değişkenine Göre Farklılaşması

\begin{tabular}{llcccc}
\hline \hline & & $\mathbf{N}$ & Mean & Std. Deviation & Sig. \\
\hline Hiperaktivite_Ort & Lise Mezunu & 6 & 2,0417 & 0,51031 & 0,047 \\
& Üniversite mezunu & 50 & 1,5300 & 0,59040 & \\
& Total & 56 & 1,5848 & 0,59977 & \\
Saldırganlık_Ort & Lise Mezunu & 6 & 1,7619 & 0,71524 & 0,134 \\
& Üniversite mezunu & 50 & 1,3971 & 0,53630 & \\
& Total & 56 & 1,4362 & 0,56188 & \\
Dişlanmış_Ort & Lise Mezunu & 6 & 1,4048 & 0,73076 & 0,285 \\
& Üniversite mezunu & 50 & 1,2143 & 0,35961 & \\
Kayg1_Korku_Ort & Total & 56 & 1,2347 & 0,40902 & \\
& Lise Mezunu & 6 & 1,7222 & 0,59109 & 0,074 \\
& Üniversite mezunu & 50 & 1,4800 & 0,26221 & \\
Asosyal_Ort & Total & 56 & 1,5060 & 0,31421 & \\
& Lise Mezunu & 6 & 1,3333 & 0,68014 & 0,992 \\
\multirow{2}{*}{ Prososyal_Ort } & Üniversite mezunu & 50 & 1,3314 & 0,43812 & \\
& Total & 56 & 1,3316 & 0,46159 & \\
& Lise Mezunu & 6 & 2,6833 & 0,38166 & 0,541 \\
& Üniversite mezunu & 50 & 2,5700 & 0,43059 & \\
\hline
\end{tabular}

Araştırmada yer alan çocuklardan akranlarına yönelik saldırganlık puanı ortalamalarının annenin eğitim düzeyi değişkeni açısından ele alındığında anlamlı bir değişiklik olup olmadığını anlamak sebebiyle gerçekleştirilen F testi çıktıları doğrultusunda; grup ortalamaları arasındaki fark anlamlı bulunmamıştır $(\mathrm{p}=0,134>0,05)$. Araştırmaya katılan çocukların akranlarına karşı yardımı amaçlayan sosyal davranış gösterme puanı ortalamalarının anne eğitim durumu değişkeni açısından ele alındığında anlamlı bir farklılık olup olmadığını belirlemek amacıyla yapılan F testi çıktıları doğrultusunda; grup ortalamaları arasındaki fark anlamlı bulunamamıştır $(\mathrm{p}=0,541>0,05)$. Araştırmaya katılan çocukların dışlanma puanı ortalamalarının anne eğitim durumu değişkeni açısından ele alındığında anlamlı bir farklılık olup olmadığını belirlemek amacıyla yapılan $\mathrm{F}$ testi çıktıları doğrultusunda; grup ortalamaları arasındaki fark anlamlı bulunamamıştır $(\mathrm{p}=0,285>0,05)$.

Araştırmaya katılan çocukların akranlarına karşı asosyal davranış geliştirme puanı ortalamalarının anne eğitim durumu değişkeni açısından ele alındığında anlamlı bir farklılık olup olmadığını belirlemek amacıyla yapılan $\mathrm{F}$ testi çıktıları doğrultusunda; grup ortalamaları arasındaki fark anlamlı bulunmamıştır $(\mathrm{p}=0,992>0,05)$. 
Araştırmaya katılan çocukların akranlarına karşı korku-kaygı duyma puanı ortalamalarının anne eğitim durumu değişkeni açısından ele alındığında anlamlı bir farklılık olup olmadığını belirlemek amaciyla yapılan $\mathrm{F}$ testi çıktıları doğrultusunda; grup ortalamaları arasındaki fark anlamlı bulunamamıştır $(\mathrm{p}=0,074>0,05)$. Araştırmaya katılan çocukların akranları tarafindan dışlanma puanı ortalamalarının anne eğitim durumu değişkeni açısından ele alındığında anlamlı bir farklılık olup olmadığını belirlemek amacıyla yapılan $\mathrm{F}$ testi çıktıları doğrultusunda; grup ortalamaları arasındaki fark anlamlı bulunmamıştır. $(\mathrm{p}=0,285>0,05)$. Araştırmaya katılan çocukların aşırı hareketlilik puanı ortalamalarının anne eğitim durumu değişkeni açısından ele alındığında anlamlı bir farklılık olup olmadığını belirlemek amacıyla yapılan F testi çıktıları doğrultusunda; grup ortalamaları arasındaki fark anlamlı bulunmuştur $(\mathrm{p}=0,047<0.05)$. Farklılığın hangi gruptan kaynaklandığını belirlemek üzere Tukey testi uygulanmıştır. Buna göre; anne eğitim durumu lise mezunu olan çocukların aşırı hareketlilik puanı $(\mathrm{x}=2,0417)$, anne eğitim durumu üniversite mezunu olan çocukların aşırı hareketlilik puanından $(x=1,5300)$ yüksek olduğu görülmektedir.

Tablo 10: Araştırmada Yer Alan Çocukların Akran İlişki Düzeylerinin Baba Eğitim Durumu Değişkenine Göre Farklılaşması

\begin{tabular}{llcccc}
\hline \hline & & N & Mean & Std. Deviation & Sig. \\
\hline Hiperaktivite_Ort & Lise mezunu & 8 & 1,9375 & 0,60872 & 0,072 \\
& Üniversite mezunu & 48 & 1,5260 & 0,58401 & \\
& Total & 56 & 1,5848 & 0,59977 & \\
Saldırganlık_Ort & Lise mezunu & 8 & 1,7857 & 0,71632 & 0,057 \\
& Üniversite mezunu & 48 & 1,3780 & 0,51843 & \\
Dişlanmış_Ort & Total & 56 & 1,4362 & 0,56188 & \\
& Lise mezunu & 8 & 1,4643 & 0,71531 & 0,086 \\
& Üniversite mezunu & 48 & 1,1964 & 0,33030 & \\
Kaygı_Korku_Ort & Total & 56 & 1,2347 & 0,40902 & \\
& Lise mezunu & 8 & 1,7222 & 0,52116 & 0,034 \\
Asosyal_Ort & Universite mezunu & 48 & 1,4699 & 0,25650 & \\
& Total & 56 & 1,5060 & 0,31421 & \\
& Lise mezunu & 8 & 1,3750 & 0,58123 & 0,777 \\
Prososyal_Ort & Universite mezunu & 48 & 1,3244 & 0,44570 & \\
& Total & 56 & 1,3316 & 0,46159 & \multirow{2}{*}{0,559} \\
& Lise mezunu & 8 & 2,5000 & 0,45040 & \\
& Üniversite mezunu & 48 & 2,5958 & 0,42274 & \\
& Total & 56 & 2,5821 & 0,42388 & \\
\hline
\end{tabular}

Araştırmada yer alan çocukların arkadaşlarına yönelik saldırganlık puanı ortalamalarının babanın eğitim düzeyine değişkeni tarafindan anlamlı bir farklılık olup olmadığını saptamak için yapılan $\mathrm{F}$ Testi sonunda; grup ortalamalarında anlamlı bir ilişki yoktur $(\mathrm{p}=0,057>0,05)$. Araştırmada yer alan çocukların akranlarına yönelik yardımı hedef alan sosyal davranış gösterme puanı ortalamalarının babanın eğitim düzeyi değişkeni tarafindan anlamlı bir farklılık olup olmadığının belirlenmesinin sebebiyle yapılan $\mathrm{F}$ Testi çıktılarına göre; grup ortalamaları arasındaki anlamlı bir ilişki yoktur. $(\mathrm{p}=0,559>0,05)$. Araştırmada yer alan çocukların akranlarına karşı asosyal davranış geliștirme puanı ortalamalarının baba eğitim durumu değişkeni açısından ele alındığında anlamlı bir farklılık olup olmadığını belirlemek amacıyla yapılan $\mathrm{F}$ testi çıktıları doğrultusunda; grup ortalamaları arasındaki fark anlamlı bulunmamıştır $(\mathrm{p}=0,777>0,05)$. Araştırmada yer alan çocukların akranlarına karşı korku-kaygı duyma puanı ortalamalarının babanın eğitim düzeyi değişkeni açısından ele alındığında anlamlı olup olmadığını belirlemek sebebiyle yapılan F Testi çıktılarına göre; grup ortalamaları arasındaki fark anlamlı bulunmuştur $(\mathrm{p}=0,034<0,05)$. Farklılığın hangi gruptan kaynaklandığını bulmak üzere Tukey testi yapılmıştır. Buna göre; babasının eğitim düzeyi üniversite mezunu olan çocukların akranları tarafından kayg1, korku puanı $(\mathrm{x}=1,4699)$, babasının eğitim durumunun lise mezunu olan çocukların akranları tarafından dışlanma puanından $(\mathrm{x}=1,7222)$ düşük olduğu görülmektedir. Araştırmada yer alan çocukların aşırı hareketlilik puanı ortalamalarının baba eğitim durumu değişkeni açısından ele alındığında anlamlı bir farklılık olup olmadığını belirlemek amacıyla yapılan F testi çıktıları doğrultusunda; grup 
ortalamaları arasındaki fark anlamlı bulunmamıştır. ( $\mathrm{p}=0,072>0,05)$. Araştırmada yer alan çocukların dışlanmışlık puanı ortalamalarının baba eğitim durumu değişkeni açısından ele alındığında anlamlı bir farklılık olup olmadığını belirlemek amacıyla yapılan $\mathrm{F}$ testinin çıktılarına ele alındığında; grup ortalamaları arasındaki fark anlamlı bulunmamıştır. $(\mathrm{p}=0,086>0,05)$.

Tablo 11: Araştırmada Yer Alan Çocukların Akran İlişki Düzeylerinin Anne Yaşı Değişkenine Göre Farklılaşması

\begin{tabular}{|c|c|c|c|c|c|c|}
\hline & & $\mathbf{N}$ & Mean & Std. Deviation & Sig. & Tukey \\
\hline \multirow{4}{*}{ Hiperaktivite_Ort } & $20-30$ yaș arası & 4 & 1,7500 & 0,54006 & 0,037 & $2-3$ \\
\hline & $31-40$ yaş aras 1 & 38 & 1,4474 & 0,51056 & & $3-2$ \\
\hline & 41 yaş ve üstü & 14 & 1,9107 & 0,73122 & & \\
\hline & Total & 56 & 1,5848 & 0,59977 & & \\
\hline \multirow[t]{4}{*}{ Saldırganlık_Ort } & $20-30$ yaş aras 1 & 4 & 2,0357 & 1,11499 & 0,019 & $1-2$ \\
\hline & $31-40$ yaş aras 1 & 38 & 1,3120 & 0,44790 & & $2-1$ \\
\hline & 41 yaş ve üstü & 14 & 1,6020 & 0,54088 & & \\
\hline & Total & 56 & 1,4362 & 0,56188 & & \\
\hline \multirow[t]{4}{*}{ Dişlanmış_Ort } & 20-30 yaş arası & 4 & 1,4286 & 0,58321 & 0,099 & - \\
\hline & $31-40$ yaş aras1 & 38 & 1,1541 & 0,29217 & & \\
\hline & 41 yaş ve üstü & 14 & 1,3980 & 0,57192 & & \\
\hline & Total & 56 & 1,2347 & 0,40902 & & \\
\hline \multirow[t]{4}{*}{ Kayg1_Korku_Ort } & 20-30 yaş arası & 4 & 1,5000 & 0,34546 & 0,018 & $2-3$ \\
\hline & $31-40$ yaş aras1 & 38 & 1,4327 & 0,24750 & & $3-2$ \\
\hline & 41 yaş ve üstü & 14 & 1,7063 & 0,39610 & & \\
\hline & Total & 56 & 1,5060 & 0,31421 & & \\
\hline \multirow[t]{4}{*}{ Asosyal_Ort } & 20-30 yaş arası & 4 & 1,5357 & 0,79433 & 0,041 & $2-3$ \\
\hline & $31-40$ yaş aras1 & 38 & 1,2256 & 0,39944 & & $3-2$ \\
\hline & 41 yaş ve üstü & 14 & 1,5612 & 0,44639 & & \\
\hline & Total & 56 & 1,3316 & 0,46159 & & \\
\hline \multirow[t]{4}{*}{ Prososyal_Ort } & 20-30 yaş arası & 4 & 2,4250 & 0,62383 & 0,041 & $1-2$ \\
\hline & $31-40$ yaş arası & 38 & 2,6789 & 0,39467 & & $2-1$ \\
\hline & 41 yaş ve üstü & 14 & 2,3643 & 0,37541 & & \\
\hline & Total & 56 & 2,5821 & 0,42388 & & \\
\hline
\end{tabular}

Araştırmada yer alan çocukların akranlarına karşı saldırganlık puanı ortalamalarının anne yaşı değişkeni açısından ele alındığında anlamlı bir farklılık olup olmadığını belirlemek sebebiyle yapılan $\mathrm{F}$ testi çiktıları doğrultusunda; grup ortalamaları arasında bulunan fark anlamlı bulunmuştur $(p=0,019<0,05)$. Farklılığın hangi gruptan kaynaklandığını belirlemek üzere Tukey testi uygulanmıştır. Bu veriler 1şığında; annesinin yaşı 20-30 yaş aralığında bulunan çocukların akranlarına karşı yardımı amaçlayan sosyal davranış gösterme puanı $(\mathrm{x}=2,0357)$, annesinin yaşı $31-40$ yaş aralığında bulunan çocukların akranlarına karşı yardımı amaçlayan sosyal davranış gösterme puanından $(\mathrm{x}=1,3120)$ yüksek olduğu görülmektedir. Araştırmada yer alan çocukların akranlarına karşı yardımı amaçlayan sosyal davranış gösterme puanı ortalamalarının anne yaşı değişkeni açısından ele alındığında anlamlı bir farklılık olup olmadığını belirlemek sebebiyle yapılan $\mathrm{F}$ testi çıktıları doğrultusunda; grup ortalamaları arasında bulunan fark anlamlı bulunmuştur $(\mathrm{p}=0,041<0,05)$. Farklılığın hangi gruptan kaynaklandığını belirlemek üzere Tukey testi uygulanmıştır. Bu veriler ışığında; annesinin yaşı 20-30 yaş aralığında bulunan çocukların akranlarına karşı yardımı amaçlayan sosyal davranış gösterme puanı $(\mathrm{x}=2,4250)$, annesinin yaşı 31-40 yaş aralığında bulunan çocukların akranlarına karşı yardımı amaçlayan sosyal davranış gösterme puanından $(\mathrm{x}=2,6789)$ düşük olduğu görülmektedir. Araştırmada yer alan çocukların akranlarına karşı asosyal davranış geliştirme puanı ortalamalarının anne yaşı değişkeni açısından ele alındığında anlamlı bir farklılık olup olmadığını belirlemek sebebiyle yapılan $F$ testi çıktıları doğrultusunda; grup ortalamaları arasında bulunan fark anlamlı bulunmuştur $(\mathrm{p}=0,041<0,05)$. Farklılığın hangi gruptan kaynaklandığını belirlemek üzere Tukey testi uygulanmıştır. Bu veriler ışığında; annesinin yaşı 41 yaş ve üstü aralığındaki çocukların akranlarına karşı asosyal davranış geliştirme puanı $(\mathrm{x}=1,5612)$, annesinin yaşı 31-40 yaş aralığında bulunan çocukların akranlarına karşı asosyal davranış 
geliştirme puanından $(x=1,2256)$ yüksek olduğu görülmektedir. Araştırmada yer alan çocukların akranlarına karşı korku-kaygı duyma puanı ortalamalarının anne yaşı değişkeni açısından ele alındığında anlamlı bir farklılık olup olmadığını belirlemek sebebiyle yapılan F testi çıktıları doğrultusunda; grup ortalamaları arasında bulunan fark anlamlı bulunmuştur $(\mathrm{p}=0,018<0,05)$. Farklılığın hangi gruptan kaynaklandığını belirlemek üzere Tukey testi uygulanmıştır. Annesinin yaş1 41 yaş ve üstü aralığındaki çocukların akranlarına karşı korku-kaygı duyma puanı $(x=1,7063)$, annesinin yaşı 31-40 yaş aralığında bulunan çocukların akranlarına karşı korku-kaygı duyma puanından $(\mathrm{x}=1,4327)$ yüksek olduğu görülmektedir. Araştırmada yer alan çocukların akranları tarafından dışlanma puanı ortalamalarının anne yaşı değişkeni açısından ele alındığında anlamlı bir farklılık olup olmadığını belirlemek sebebiyle yapılan F testi çıktıları doğrultusunda; grup ortalamaları arasında bulunan fark anlamlı bulunmamıştır $(\mathrm{p}=0,099>0,05)$. Araştırmada yer alan çocukların aşırı hareketlilik puanı ortalamalarının anne yaşı değişkeni açısından ele alındığında anlamlı bir farklılık olup olmadığını belirlemek sebebiyle yapılan F testi çıktıları doğrultusunda; grup ortalamaları arasında bulunan fark anlamlı bulunmuştur $(\mathrm{p}=0,037<0,05)$. Farklılığın hangi gruptan kaynaklandığını belirlemek üzere Tukey testi uygulanmıştır. $\mathrm{Bu}$ veriler ışığında; annesinin yaşı 41 yaş ve üstü aralığındaki çocukların aşırı hareketlilik puanı $(\mathrm{x}=1,9107)$, annesinin yaşı $31-40$ yaş aralığında bulunan çocukların aşırı hareketlilik puanından $(\mathrm{x}=1,4474)$ yüksek olduğu görülmektedir.

Tablo 12: Araştırmada yer alan Çocukların Akran İlişki Düzeylerinin Baba Yaşı Değişkenine Göre Farklılaşması

\begin{tabular}{|c|c|c|c|c|c|c|}
\hline & & $\mathbf{N}$ & Mean & Std. Deviation & $\mathbf{F}$ & Sig. \\
\hline \multirow{3}{*}{ Hiperaktivite_Ort } & $31-40$ yaş arası & 40 & 1,4688 & 0,50696 & 5,691 & 0,021 \\
\hline & 41 yaș ve üstü & 16 & 1,8750 & 0,72457 & & \\
\hline & Total & 56 & 1,5848 & 0,59977 & & \\
\hline \multirow[t]{3}{*}{ Saldırganlık_Ort } & $31-40$ yaş aras1 & 40 & 1,3500 & 0,51248 & 3,443 & 0,069 \\
\hline & 41 yaş ve üstü & 16 & 1,6518 & 0,63668 & & \\
\hline & Total & 56 & 1,4362 & 0,56188 & & \\
\hline \multirow[t]{3}{*}{ Dışlanmış_Ort } & $31-40$ yaş aras1 & 40 & 1,1571 & 0,28535 & 5,439 & 0,023 \\
\hline & 41 yaș ve üstü & 16 & 1,4286 & 0,58786 & & \\
\hline & Total & 56 & 1,2347 & 0,40902 & & \\
\hline \multirow[t]{3}{*}{ Kayg1_Korku_Ort } & $31-40$ yaş aras1 & 40 & 1,4361 & 0,24445 & 7,768 & 0,007 \\
\hline & 41 yaş ve üstü & 16 & 1,6806 & 0,40139 & & \\
\hline & Total & 56 & 1,5060 & 0,31421 & & \\
\hline \multirow[t]{3}{*}{ Asosyal_Ort } & $31-40$ yaş aras1 & 40 & 1,2179 & 0,39088 & 9,879 & 0,003 \\
\hline & 41 yaş ve üstü & 16 & 1,6161 & 0,51301 & & \\
\hline & Total & 56 & 1,3316 & 0,46159 & & \\
\hline \multirow[t]{3}{*}{ Prososyal_Ort } & $31-40$ yaş aras1 & 40 & 2,6800 & 0,38511 & 8,476 & 0,005 \\
\hline & 41 yaş ve üstü & 16 & 2,3375 & 0,42876 & & \\
\hline & Total & 56 & 2,5821 & 0,42388 & & \\
\hline
\end{tabular}

Araştırmada yer alan çocukların akranlarına karşı saldırganlık puanı ortalamalarının baba yaşı değişkeni açısından ele alındığında anlamlı bir farklılık olup olmadığını belirlemek sebebiyle yapılan $F$ testi çıtıları doğrultusunda; grup ortalamaları arasında bulunan fark anlamlı bulunmamıştır $(p=0,069>0,05)$. Araşıırmada yer alan çocukların akranlarına karşı yardımı amaçlayan sosyal davranış gösterme puanı ortalamalarının baba yaşı değişkeni açısından ele alındığında anlamlı bir farklılık olup olmadığını belirlemek sebebiyle yapılan $\mathrm{F}$ testi çıtıları doğrultusunda; grup ortalamaları arasında bulunan fark anlamlı bulunmuştur $(\mathrm{p}=0,005<0,05)$. Farklılı̆ı̆ hangi gruptan kaynaklandığını belirlemek üzere Tukey testi uygulanmıştır. Bu veriler ışığında; babasının yaşı 31-40 yaş aralığında bulunan çocukların akranlarına karşı yardımı amaçlayan sosyal davranış gösterme puanı $(x=2,6800)$, babasının yaşı 41 yaş ve üstü aralığındaki çocukların akranlarına karşı yardımı amaçlayan sosyal davranış gösterme puanından $(x=2,3375)$ yüksek olduğu görülmektedir.

Araştırmada yer alan çocukların akranlarına karşı asosyal davranış geliştirme puanı ortalamalarının baba yaşı değişkeni açısından ele alındığında anlamlı bir farklılık olup olmadığını belirlemek sebebiyle 
yapılan $\mathrm{F}$ testi çıktıları doğrultusunda; grup ortalamaları arasında bulunan fark anlamlı bulunmuştur $(\mathrm{p}=0,003<0,05)$. Farklılığın hangi gruptan kaynaklandığını belirlemek üzere Tukey testi uygulanmıştır. $\mathrm{Bu}$ veriler 1şığında; babasının yaşı 41 yaş ve üstü aralığındaki çocukların akranlarına karşı asosyal davranış geliştirme puanı $(\mathrm{x}=1,6161)$, babasının yaşı $31-40$ yaş aralığında bulunan çocukların akranlarına karşı asosyal davranış geliştirme puanından $(\mathrm{x}=1,2179)$ yüksek olduğu görülmektedir. Araştırmada yer alan çocukların akranlarına karşı korku-kaygı duyma puanı ortalamalarının baba yaşı değişkeni açısından ele alındığında anlamlı bir farklılık olup olmadığını belirlemek sebebiyle yapılan $F$ testi çıktıları doğrultusunda; grup ortalamaları arasında bulunan fark anlamlı bulunmuştur $(\mathrm{p}=0,007<0,05)$. Farklılığın hangi gruptan kaynaklandığını belirlemek üzere Tukey testi uygulanmıştır. Bu veriler ışı̆̆ında; babasının yaşı 41 ve üzeri yaş aralığındaki çocukların akranlarına karşı korku-kaygı duyma puanı $(x=1,6806)$, babasının yaşı 31-40 yaş aralığında bulunan çocukların akranlarına karşı korku-kaygı duyma puanından $(x=1,4361)$ yüksek olduğu görülmektedir. Araştırmada yer alan çocukların akranları tarafindan dışlanma puanı ortalamalarının baba yaşı değişkeni açısından ele alındığında anlamlı bir farklılık olup olmadığını belirlemek sebebiyle yapılan $\mathrm{F}$ testi çıktıları doğrultusunda; grup ortalamaları arasında bulunan fark anlamlı bulunmuştur ( $\mathrm{p}=0,023>0,05)$. Farklılı̆̆ın hangi gruptan kaynaklandığını belirlemek üzere Tukey testi uygulanmıştır. $\mathrm{Bu}$ veriler ışığında; babasının yaşı 41 ve üzeri yaş aralığındaki çocukların akranlarına karşı dışlanmışlık puanı $(\mathrm{x}=1,4286)$, babasının yaşı 31-40 yaş aralığında bulunan çocukların akranlarına karşı korku-kaygı duyma puanından $(\mathrm{x}=1,1571)$ yüksek olduğu görülmektedir. Araştırmada yer alan çocukların aşırı hareketlilik puanı ortalamalarının baba yaşı değişkeni açısından ele alındığında anlamlı bir farklılık olup olmadığını belirlemek sebebiyle yapılan $\mathrm{F}$ testi çıktıları doğrultusunda; grup ortalamaları arasında bulunan fark anlamlı bulunmuştur $(\mathrm{p}=0,021<0,05)$. Farklılığın hangi gruptan kaynaklandığını belirlemek üzere Tukey testi uygulanmıştır. Bu veriler ışığında; babasının yaşı 41 yaş ve üstü aralığındaki çocukların aşırı hareketlilik puanı $(\mathrm{x}=1,8750)$, babasının yaşı $31-40$ yaş aralığında bulunan çocukların aşırı hareketlilik puanından $(x=1,4688)$ yüksek olduğu görülmektedir.

Tablo 13: Araştırmada yer alan Çocukların Akran İlişki Düzeylerinin Kardeş Sayısı Değişkenine Göre

\begin{tabular}{|c|c|c|c|c|c|c|}
\hline & & $\overline{\mathbf{N}}$ & Mean & Std. Deviation & $\mathbf{F}$ & Sig. \\
\hline \multirow[t]{4}{*}{ Hiperaktivite_Ort } & Kardeşi yok & 34 & 1,5588 & 0,56091 & 0,216 & 0,807 \\
\hline & 1 kardesi var & 17 & 1,6618 & 0,71229 & & \\
\hline & 3 kardeși var & 5 & 1,5000 & 0,53033 & & \\
\hline & Total & 56 & 1,5848 & 0,59977 & & \\
\hline \multirow[t]{4}{*}{ Saldırganlık_Ort } & Kardeşi yok & 34 & 1,4328 & 0,57840 & 0,054 & 0,948 \\
\hline & 1 kardeşi var & 17 & 1,4202 & 0,46694 & & \\
\hline & 3 kardeşi var & 5 & 1,5143 & 0,83666 & & \\
\hline & Total & 56 & 1,4362 & 0,56188 & & \\
\hline \multirow[t]{4}{*}{ Dişlanmış_Ort } & Kardeşi yok & 34 & 1,1849 & 0,35262 & 0,787 & 0,461 \\
\hline & 1 kardeşi var & 17 & 1,2857 & 0,48181 & & \\
\hline & 3 kardeşi var & 5 & 1,4000 & 0,52876 & & \\
\hline & Total & 56 & 1,2347 & 0,40902 & & \\
\hline \multirow[t]{4}{*}{ Kayg1_Korku_Ort } & Kardeşi yok & 34 & 1,5000 & 0,24504 & 0,025 & 0,975 \\
\hline & 1 kardeşi var & 17 & 1,5098 & 0,44106 & & \\
\hline & 3 kardeşi var & 5 & 1,5333 & 0,28760 & & \\
\hline & Total & 56 & 1,5060 & 0,31421 & & \\
\hline \multirow[t]{4}{*}{ Asosyal_Ort } & Kardeşi yok & 34 & 1,2311 & 0,32043 & 2,641 & 0,081 \\
\hline & 1 kardeşi var & 17 & 1,4370 & 0,56350 & & \\
\hline & 3 kardeşi var & 5 & 1,6571 & 0,73955 & & \\
\hline & Total & 56 & 1,3316 & 0,46159 & & \\
\hline \multirow[t]{4}{*}{ Prososyal_Ort } & Kardeşi yok & 34 & 2,6059 & 0,42707 & 0,207 & 0,814 \\
\hline & 1 kardeşi var & 17 & 2,5647 & 0,39042 & & \\
\hline & 3 kardeşi var & 5 & 2,4800 & 0,58052 & & \\
\hline & Total & 56 & 2,5821 & 0,42388 & & \\
\hline
\end{tabular}


Araştırmada yer alan çocukların akranlarına karşı saldırganlık puanı ortalamalarının kardeş sayısı değişkeni açısından ele alındığında anlamlı bir farklılık olup olmadığını belirlemek sebebiyle yapılan t testi sonuçlarına göre; grup ortalamaları arasında bulunan fark anlamlı bulunmamışırı $(p=0,948>0,05)$. Araştırmada yer alan çocukların akranlarına karşı yardımı amaçlayan sosyal davranış gösterme puanı ortalamalarının kardeş sayısı değişkeni açısından ele alındığında anlamlı bir farklılık olup olmadığını belirlemek sebebiyle yapılan $t$ testi sonuçlarına göre; grup ortalamaları arasında bulunan fark anlamlı bulunmamışırır $(\mathrm{p}=0,814>0,05)$. Araştırmada yer alan çocukların akranlarına karşı asosyal davranış geliştirme puanı ortalamalarının kardeş sayısı değişkeni açısından ele alındığında anlamlı bir farklılık olup olmadığını belirlemek sebebiyle yapılan $t$ testi sonuçlarına göre; grup ortalamaları arasında bulunan fark anlamlı bulunmamıştır $(\mathrm{p}=0,081>0,05)$. Araştırmada yer alan çocukların akranlarına karşı korkukaygı duyma puanı ortalamalarının kardeş sayısı değişkeni açısından ele alındığında anlamlı bir farklılık olup olmadığını belirlemek sebebiyle yapılan $t$ testi sonuçlarına göre; grup ortalamaları arasında bulunan fark anlamlı bulunmamışır $(\mathrm{p}=0,975>0,05)$. Araştırmada yer alan çocukların akranları tarafından dışlanma puanı ortalamalarının kardeş sayısı değişkeni açısından ele alındığında anlamlı bir farklılık olup olmadığını belirlemek sebebiyle yapılan $t$ testi sonuçlarına göre; grup ortalamaları arasında bulunan fark anlamlı bulunmamıştır ( $\mathrm{p}=0,461>0,05)$. Araştırmada yer alan çocukların aşırı hareketlilik puanı ortalamalarının kardeş sayısı değişkeni açısından ele alındığında anlamlı bir farklılık olup olmadığını belirlemek sebebiyle yapılan t testi sonuçlarına göre; grup ortalamaları arasında bulunan fark anlamlı bulunmamışır $(\mathrm{p}=0,807>0,05)$.

\section{Araştırmada Yer Alan Çocukların Öz Düzenleme Beceri Düzeylerinin Aralarındaki İlişkinin Korelasyon Analizi İle İncelenmesi}

Tablo 14: Araştırmada yer alan Çocukların Akran İlişki Düzeylerinin Aralarındaki İlişkinin Korelasyon Analizi ile İncelenmesi

\begin{tabular}{|c|c|c|c|c|c|c|}
\hline & & $\begin{array}{l}\text { Dikkat } \\
\text { Ort. }\end{array}$ & $\begin{array}{l}\text { Dürtü } \\
\text { Kont Ort. }\end{array}$ & $\begin{array}{l}\text { Aktivite } \\
\text { Düz Ort. }\end{array}$ & $\begin{array}{l}\text { Sosyallik } \\
\text { Düz Ort. }\end{array}$ & $\begin{array}{l}\text { Duygu Enerji } \\
\text { Ort. }\end{array}$ \\
\hline \multirow[t]{3}{*}{ Dikkat Ort. } & Pearson Correlation & 1 & $285^{*}$ &, $337^{*}$ & 0,123 &,$- 272^{*}$ \\
\hline & Sig. (2-tailed) & & 0,034 & 0,011 & 0,366 & 0,042 \\
\hline & $\mathrm{N}$ & 56 & 56 & 56 & 56 & 56 \\
\hline \multirow[t]{3}{*}{ Dürtü Kont Ort. } & Pearson Correlation & $285^{*}$ & 1 & ,309* & 0,104 & $-0,022$ \\
\hline & Sig. (2-tailed) & 0,034 & & 0,020 & 0,443 & 0,874 \\
\hline & $\mathrm{N}$ & 56 & 56 & 56 & 56 & 56 \\
\hline \multirow[t]{3}{*}{ Aktivite Düz Ort. } & Pearson Correlation &, $337^{*}$ &, $309^{*}$ & 1 &, $734^{* *}$ &, $387^{* *}$ \\
\hline & Sig. (2-tailed) & 0,011 & 0,020 & & 0,000 & 0,003 \\
\hline & $\mathrm{N}$ & 56 & 56 & 56 & 56 & 56 \\
\hline \multirow[t]{3}{*}{ Sosyallik Düz Ort. } & Pearson Correlation & 0,123 & 0,104 &, $734^{* *}$ & 1 &, $457^{* *}$ \\
\hline & Sig. (2-tailed) & 0,366 & 0,443 & 0,000 & & 0,000 \\
\hline & $\mathrm{N}$ & 56 & 56 & 56 & 56 & 56 \\
\hline \multirow[t]{3}{*}{ Duygu Enerji Ort. } & Pearson Correlation &,$- 272^{*}$ & $-0,022$ &, $387^{* *}$ &, $457^{* *}$ & 1 \\
\hline & Sig. (2-tailed) & 0,042 & 0,874 & 0,003 & 0,000 & \\
\hline & $\mathrm{N}$ & 56 & 56 & 56 & 56 & 56 \\
\hline \multirow[t]{3}{*}{ Hiperaktivite Ort. } & Pearson Correlation &,$- 433^{* *}$ & $-0,176$ & $-0,250$ & $-0,115$ & 0,146 \\
\hline & Sig. (2-tailed) & 0,001 & 0,194 & 0,063 & 0,400 & 0,283 \\
\hline & $\mathrm{N}$ & 56 & 56 & 56 & 56 & 56 \\
\hline \multirow[t]{3}{*}{ Saldırganlık Ort. } & Pearson Correlation &,$- 384^{* *}$ & $-0,132$ & $-0,145$ & 0,080 & 0,095 \\
\hline & Sig. (2-tailed) & 0,003 & 0,333 & 0,286 & 0,557 & 0,484 \\
\hline & $\mathrm{N}$ & 56 & 56 & 56 & 56 & 56 \\
\hline \multirow[t]{3}{*}{ Dişlanmış Ort. } & Pearson Correlation &,$- 542^{* *}$ & $-0,224$ &,$- 550^{* *}$ & $-0,195$ & 0,070 \\
\hline & Sig. (2-tailed) & 0,000 & 0,096 & 0,000 & 0,149 & 0,608 \\
\hline & $\mathrm{N}$ & 56 & 56 & 56 & 56 & 56 \\
\hline \multirow[t]{3}{*}{ Kaygı Korku Ort. } & Pearson Correlation &,$- 383^{* *}$ &,$- 294^{*}$ &,$- 455^{* *}$ & $-0,233$ & 0,133 \\
\hline & Sig. (2-tailed) & 0,004 & 0,028 & 0,000 & 0,084 & 0,329 \\
\hline & $\mathrm{N}$ & 56 & 56 & 56 & 56 & 56 \\
\hline
\end{tabular}




\begin{tabular}{lllllll} 
Asosyal Ort. & Pearson Correlation &,$- 271^{*}$ & $-0,127$ &,$- 661^{* *}$ &,$- 446^{* *}$ & $-0,081$ \\
& Sig. (2-tailed) & 0,043 & 0,351 & 0,000 & 0,001 & 0,551 \\
& N & 56 & 56 & 56 & 56 & 56 \\
Prososyal_Ort. & Pearson Correlation &, $339^{*}$ & 0,135 &, $383^{* *}$ &, $324^{*}$ & $-0,062$ \\
& Sig. (2-tailed) & 0,011 & 0,321 & 0,004 & 0,015 & 0,650 \\
& N & 56 & 56 & 56 & 56 & 56 \\
\hline
\end{tabular}

Araştırmada yer alan çocukların akran ilişki düzeylerinin aralarındaki ilişkinin korelasyon analizi ile incelendiğinde dikkat ile dürtü kontrolünü arasında bulunan ilişkiyi belirlemek üzere yapılan korelasyon analizi sonucunda, puanlar arasında \%34 düzeyinde pozitif yönde anlamlı ilişki bulunmuştur. $(r=-0,285$; $\mathrm{p}=0,034<0,05)$. Bu veriler 1şığında dikkat puanı arttıkça dürtü kontrolü puanı artmaktadır.

Davranış düzenleme ile dikkat arasında bulunan ilişkiyi belirlemek üzere yapılan korelasyon analizi sonucunda, puanlar arasında $\% 33,7$ düzeyinde pozitif yönde anlamlı ilişki bulunmuştur. ( $r=0,337$; $\mathrm{p}=0,011<0,05)$. $\mathrm{Bu}$ veriler 1 şığında davranış düzenleme puanı arttıkça dikkat puanı da artmaktadır. Dikkat ile duygu enerji puanı arasında bulunan ilişkiyi belirlemek üzere yapılan korelasyon analizi sonucunda, puanlar arasında \%27,2 düzeyinde negatif yönde anlamlı ilişki bulunmuştur. ( $\mathrm{r}=-0,272$; $\mathrm{p}=0,042<0,05)$. Bu veriler ışığında dikkat puanı arttıkça duygu enerji puanı da azalmaktadır.

Dürtü kontrolü ile davranış düzenleme arasında bulunan ilişkiyi belirlemek üzere yapılan korelasyon analizi sonucunda, puanlar arasında \%30,9 düzeyinde pozitif yönde anlamlı ilişki bulunmuştur. $(r=0,309$; $\mathrm{p}=0,020<0,05)$. Bu veriler 1şığında dürtü kontrolü puanı arttıkça davranış düzenleme puanı da artmaktadir.

Davranış düzenleme ile sosyallik düzeyi arasında bulunan ilişkiyi belirlemek üzere yapılan korelasyon analizi sonucunda, puanlar arasında \%73,4 düzeyinde pozitif yönde anlamlı ilişki bulunmuştur. $(r=0,737$; $\mathrm{p}=0,000<0,05)$. Bu veriler ışığında davranış düzenleme puanı arttıkça sosyallik puanı da artmaktadır.

Davranış düzenleme ile duygu enerji arasında bulunan ilişkiyi belirlemek üzere yapılan korelasyon analizi sonucunda, puanlar arasında $\% 38,7$ düzeyinde pozitif yönde anlamlı ilişki bulunmuştur. $(\mathrm{r}=0,387$; $\mathrm{p}=0,003<0,05)$. Bu veriler ışığında davranış düzenleme puanı arttıkça duygu enerji puanı da artmaktadır.

Sosyallik düzeyi ile duygu enerji arasında bulunan ilişkiyi belirlemek üzere yapılan korelasyon analizi sonucunda, puanlar arasında \%45,7 düzeyinde pozitif yönde anlamlı ilişki bulunmuştur. ( $\mathrm{r}=-0,457$; $\mathrm{p}=0,000<0,05)$. Bu veriler ışığında sosyallik puanı arttıkça duygu enerji puanı artmaktadır.

Aşırı hareketlilik ile dikkat arasında bulunan ilişkiyi belirlemek üzere yapılan korelasyon analizi sonucunda, puanlar arasında \%43,3 düzeyinde negatif yönde anlamlı ilişki bulunmuştur. ( $\mathrm{r}=-0,433$; $\mathrm{p}=0,001<0,05)$. Bu veriler ışığında aşırı hareketlilik puanı arttıkça dikkat puanı azalmaktadır.

Saldırganlık ile dikkat arasında bulunan ilişkiyi belirlemek üzere yapılan korelasyon analizi sonucunda, puanlar arasında \%38,4 düzeyinde negatif yönde anlamlı ilişki bulunmuştur. $(r=-0,384 ; p=0,003<0,05)$. Saldırganlık puanı arttıkça dikkat puanı azalmaktadır.

Dışlanmışlık ile dikkat arasında bulunan ilişkiyi belirlemek üzere yapılan korelasyon analizi sonucunda, puanlar arasında \%54,2 düzeyinde negatif yönde anlamlı ilişki bulunmuştur. $(r=-0,542 ; \mathrm{p}=0,000<0,05)$. Dışlanmışılı puanı arttıkça dikkat puanı azalmaktadır.

Dışlanmışlık ile davranış düzenleme arasında bulunan ilişkiyi belirlemek üzere yapılan korelasyon analizi sonucunda, puanlar arasında $\% 55,0$ düzeyinde negatif yönde anlamlı ilişki bulunmuştur. ( $\mathrm{r}=-$ $0,550 ; \mathrm{p}=0,000<0,05)$. Bu veriler 1 şı̆̆ında dışlanmışlık puanı arttıkça davranış düzenleme puanı azalmaktadır.

Korku-kaygı duyma ile dikkat arasında bulunan ilişkiyi belirlemek üzere yapılan korelasyon analizi sonucunda, puanlar arasında \%38,3 düzeyinde negatif yönde anlamlı ilişki bulunmuştur. $(\mathrm{r}=-0,383$; $\mathrm{p}=0,004<0,05)$. Bu veriler ışığında korku-kaygı duyma puanı dikkat puanı da azalır.

Korku-kaygı duyma ile dürtü kontrolü arasında bulunan ilişkiyi belirlemek üzere yapılan korelasyon analizi sonucunda, puanlar arasında \%29,4 düzeyinde negatif yönde anlamlı ilişki bulunmuştur. ( $\mathrm{r}=-$ 
0,294; $\mathrm{p}=0,028<0,05)$. Bu veriler 1 ş̧ı̆ında Korku-kaygı duyma puanı arttıkça dürtü kontrolü puanı da azalmaktadır.

Korku-kaygı duyma ile davranış düzenleme arasında bulunan ilişkiyi belirlemek üzere yapılan korelasyon analizi sonucunda, puanlar arasında \%45,5 düzeyinde negatif yönde anlamlı ilişki bulunmuştur. $(\mathrm{r}=-0,455 ; \mathrm{p}=0,000<0,05)$. Bu veriler ışığında Korku-kaygı duyma puanı arttıkça davranış düzenleme puanı azalmaktadır.

Asosyallik ile dikkat arasında bulunan ilişkiyi belirlemek üzere yapılan korelasyon analizi sonucunda, puanlar arasında \%27,1 düzeyinde negatif yönde anlamlı ilişki bulunmuştur. $(r=-0,271 ; p=0,043<0,05)$. Asosyallik puanı arttıkça dikkat puanı da azalmaktadır.

Asosyallik ile davranış düzenleme arasında bulunan ilişkiyi belirlemek üzere yapılan korelasyon analizi sonucunda, puanlar arasında \%66,1 düzeyinde negatif yönde anlamlı ilişki bulunmuştur. ( $\mathrm{r}=-0,661$; $\mathrm{p}=0,000<0,05)$. Bu veriler ışığında asosyallik puanı arttıkça davranış düzenleme puanı da artmaktadır.

Asosyallik ile sosyallik düzeyi arasında bulunan ilişkiyi belirlemek üzere yapılan korelasyon analizi sonucunda, puanlar arasında \%44,6 düzeyinde negatif yönde anlamlı ilişki bulunmuştur. $(r=-0,446$; $\mathrm{p}=0,001<0,05)$. Bu veriler 1şığında asosyallik puanı arttıkça sosyallik puanı da azalmaktadır.

Akranlarına karşı yardımı amaçlayan sosyal davranış gösterme ile dikkat arasında bulunan ilişkiyi belirlemek üzere yapılan korelasyon analizi sonucunda, puanlar arasında \%33,9 düzeyinde pozitif yönde anlamlı ilişki bulunmuştur. $(\mathrm{r}=0,339 ; \mathrm{p}=0,011<0,05)$. Bu veriler 1şığında Akranlarına karşı yardımı amaçlayan sosyal davranış gösterme puanı arttıkça dikkat puanı da artmaktadır.

Akranlarına karşı yardımı amaçlayan sosyal davranış gösterme ile davranış düzenleme arasında bulunan ilişkiyi belirlemek üzere yapılan korelasyon analizi sonucunda, puanlar arasında $\% 38,3$ düzeyinde pozitif yönde anlamlı ilişki bulunmuştur. $(\mathrm{r}=0,383 ; \mathrm{p}=0,004<0,05)$. Bu veriler 1şığında akranlarına karşı yardımı amaçlayan sosyal davranış gösterme puanı arttıkça davranış düzenleme puanı da artmaktadır.

Akranlarına karşı yardımı amaçlayan sosyal davranış gösterme ile sosyallik arasında bulunan ilişkiyi belirlemek üzere yapılan korelasyon analizi sonucunda, puanlar arasında $\% 32,4$ düzeyinde pozitif yönde anlamlı ilişki bulunmuştur. $(r=0,324 ; p=0,015<0,05)$. Bu veriler ışığında akranlarına karşı yardımı amaçlayan sosyal davranış gösterme puanı arttıkça sosyallik puanı da artmaktadır.

\section{SONUÇ VE TARTIŞMA}

Kişisel bilgi formu, Ladd ve Profilet Çocuk Davranış ölçeği ve Okul Öncesi Öz Düzenleme Ölçeği ile veriler toplanmış ve 66 ayını doldurmuş, okul öncesi eğitime devam eden çocukların öz düzenleme becerileri ile akran ilişkileri arasında bulunan ilişkiler incelenmiştir.

Öz düzenleme ve akran ilişkileri ilişkisi incelendiğinde dikkat puanı arttıkça dürtü kontrolü puanının arttığı, davranış düzenleme puanı arttıkça dikkat puanının arttığı, dikkat puanı arttıkça duygu enerji puanın azaldığı, dürtü kontrolü puanı arttıkça davranış düzenleme puanının arttı̆̆ gözlemlenmiştir. Ayrıca, davranış düzenleme puanı arttıkça sosyallik puanı, sosyallik puanı arttıkça duygu enerji puanı artmaktadır.

Aşırı hareketlilik puanı arttıkça dikkat puanının azaldığı, saldırganlık puanı arttıkça dikkat puanının azaldığı, dışlanmışlık puanı arttıkça dikkat puanının ve davranış düzenleme puanının azaldığı sonuçlarına ulaşılmıştır. Korku-kaygı duyma puanı arttıkça dikkat puanı, davranış düzenleme puanı ve dürtü kontrolü puanı azalırken, asosyallik puanı arttıkça davranış düzenleme puanı artmakta, asosyallik puanı arttıkça sosyallik puanı azalmaktadır. Bradley (2002)'nin akran ilişkileri ile çocukların öz düzenleme becerileri gelişirken, sosyal davranışları, toplumun kurallarını ve sosyal değerleri öğrendikleri ifadesi ile araştırma sonuçları benzerlik göstermektedir.

Arkadaşlık ilişkilerinde sorun yaşayan çocukların, daha az olumlu sosyal davranış sergilediklerini Wentzel, McNamara-Barry ve Caldwell (2004) yaptıkları araştırmalar sonucu ortaya çıkarmışlardır. Araştırmadaki akranlarına karşı yardımı amaçlayan sosyal davranış gösterme puanı arttıkça dikkat puanı, 
davranış düzenleme puanı ve sosyallik puanından gözlenen artış Wentzel, McNamara-Barry ve Caldwell (2004)'in çalışmalarında ulaştıkları sonucu destekler niteliktedir.

$\mathrm{Bu}$ çalışmada elde edilen veriler sonucu öz düzenleme becerileri ile akran ilişkileri arasında anlamlı bir ilişki olduğu ortaya çıkmaktadır.

\section{ÖNERILER}

$\mathrm{Bu}$ çalışmaya düşük öz düzenleme becerileri gösteren çocukların, akran ilişkilerinde sorun yaşayacağı hipotezi ile yola çıkılmıştır.

-Çalışma sonucunda dikkat süresi uzun çocukların dürtü kontrolünde başarılı oldukları görülmüştür. Dürtü kontrolü arttıkça, davranış kontrolünün de arttığı sonucuna verilerin analizi sonucu ulaşılmıştır. $\mathrm{Bu}$ doğrultuda dürtü kontrolünde sorun yaşayan çocuklar için, dikkat geliştirmeye yönelik yapılacak etkinlik planlamaları ile dürtü kontrolü desteklenirken, davranış kontrolü de desteklenecektir.

-Davranış düzenleme puanının artmasıyla sosyallik puanının arttığı ölçülmüştür. Bu doğrultuda asosyal davranış gösteren çocuklar için, davranış düzenlemeyi destekleyici çalışmaların eğitim planına eklenmesi olumlu sosyal becerileri destekleyecektir.

-Aşırı hareketlilik ve saldırganlık puanları arttıkça dikkat puanı düşmektedir. Aşırı hareketli ve/veya saldırgan davranışlar gösteren çocukların, bu enerjilerini boşaltabilecekleri ve rahatlamalarını sağlayacak etkinliklere eğitim planında yer verilmesi veya çocuğun bu tür aktivitelere okul dışında yönlendirilmesi aşırı hareketlilik ve saldırganlık davranışında azalma sağlarken dikkatin artmasını destekleyecektir.

-Korku-kaygı duyma puanının artması; dikkat puanı, davranış düzenleme puanı ve dürtü kontrolü puanında azalmaların görülmesine neden olmaktadır. Korkulu-kaygılı çocukların ve kaygılarının temelinin, öğretmenin sınıf içindeki gözlemleri ve psikolojik danışmanlık ve rehberlik biriminin çalışmaları ile tespit edilmesi gerekmektedir. Tespit edilen kaygılar ve nedenleri doğrultusunda yapılacak olan rehberlik çalışmaları, sınıf içi düzenlemeler ve gerekli görülürse psikolojik danışmanlık merkezlerinden alınacak destek ile çocuğun kaygı-korkularının önüne geçilebilir. Ancak korku-kaygı duymanın olumsuz etkileri ortadan kaldırıldıktan sonra dikkat, davranış düzenleme ve dürtü kontrolünde artış gözlenmesi beklenebilir.

Çalışmada elde edilen veriler sonucu, okul öncesi eğitim kurumunda yapılacak olan planlama çalışmaları ve rehberlik çalışmaları ile akran ilişkileri ile öz düzenleme becerileri arasındaki varlığı tespit edilen olumlu ilişkilerin desteklenmesi, olumsuz ilişkilerin olumlu yönde gelişmesi sağlanabilir.

Bilgilendirme/Acknowledgement: Makale, aynı başlklı yüksek lisans tezinden türetilmiştir.

\section{KAYNAKÇA}

Ahioğlu, N. (2008). Kültürel - tarihsel kuram çerçevesinde çocuk gelişimi. Ankara Üniversitesi Eğitim Bilimleri Fakültesi Dergisi, 41(1), 163-186.

Aksoy, A. B., ve Tozduman, K. (2017). Çocukların öz düzenleme becerileri ile oyun becerilerinin cinsiyete göre incelenmesi. Trakya Üniversitesi Eğitim Fakültesi Dergisi, 7(2),261-283.

Bodrova, E., Germeroth, C., ve Leong, D. J. (2013). Play and self-regulation: Lessons from Vygotsky. American Journal of Play, 6(1), 111-123.

Bradley, K. D. (2002). Group entry strategies of socially excluded children as a function of sex, ethnicity, and sociometric status. Unpublished doctorate dissertation, The University of Texas, USA. 
Dinçer, B. (2008). Alt ve üst sosyo-ekonomik düzeyde lise ikinci sinıfa devam eden ergenlerin baba baba tutumlarını algılamaları ile arkadaşlık ilişkilerinin incelenmesi. Yayınlanmamış yüksek lisans tezi, Ankara Üniversitesi, Sosyal Bilimler Enstitüsü, Ankara.

Doll, B., Murphy, P., ve Song, S. Y. (2003). The relationship between children's self-reported recess problems, and peer acceptance and friendships. Journal of School Psychology, 41(2), 113130.

Eisenberg, N., ve Mussen, P. H. (1989). The roots of prosocial behavior in children. UK: Cambridge University Press.

Erol, A., ve İvrendi, A. (2018). 4-6 yaş çocuklarına yönelik öz-düzenleme becerileri ölçeğinin geliştirilmesi (baba formu). Pamukkale Üniversitesi Eğitim Fakültesi Dergisi, 44(44), 178195.

Gander, M. J. ve Gardiner, H. W. (1998). Çocuk ve ergen gelişimi. (Çev. Bekir Onur). Ankara: İmge Kitapevi.

Gulay, H., ve Akman, B. (2009). Social skills in preschool period. Ankara, Turkey: PEGEM-A Publishing.

Gülay, H. (2008). 5-6 yaş çocuklarına yönelik akran ilişkileri ölçeklerinin geçerlik güvenirlik çalışmaları ve akran ilişkilerinin çeşitli değişkenler açısından incelenmesi. Selcuk University Journal of Institute of Social Sciences, 30, 153-163

Gülay, H. (2010). Okul öncesi dönemde akran ilişkileri. Ankara: Pegem Akademi Yayıncılık.

Huh, Y., Ahn, D. H., Choi, J. H., Kang, J. Y., Kim, Y. Y., ve Oh, K. J. (2003). Development of a child problem-behavior screening test. Journal of Korean Neuropsychiatric Association, 42(6), 724-735.

Karasar, N. (2005). Bilimsel araştırma yöntemi. (17. Baskı). Ankara: Nobel yayın dağııım.

Ladd, G. W. and Profilet, S. M. 1996. The child behavior scale: A teacherreport measure of young children's aggressive, withdrawn, and prosocial behaviors. Developmental Psychology, 32(6), 1008- 1024.

McCabe, L. A., Cunnington, M., ve Brooks-Gunn, J. (2004). The development of self-regulation in young children: Individual characteristics and environmental contexts. In R. F. Baumeister \& K. D. Vohs (Eds.), Handbook of self-regulation: Research, theory, and applications (pp. 340-356). New York, NY, US: The Guilford Press.

McClelland, M. M., ve Morrison, F. J. (2003). The emergence of learning-related social skills in preschool children. Early Childhood Research Quarterly, 18(2), 206-224.

Posner, M. I., ve Rothbart, M. K. (2009). Toward a physical basis of attention and selfregulation. Physics of life reviews, 6(2), 103-120.

Savina, E. (2014). Does play promote self-regulation in children? Early Child Development and Care, 184(11), 1692-1705.

Schrepferman, L. M., Eby, J., Snyder, J., ve Stropes, J. (2006). Early affiliation and social engagement with peers: Prospective risk and protective factors for childhood depressive behaviors. Journal of Emotional and Behavioral Disorders, 14(1), 50-61.

Tanrıbuyurdu, E. F., ve Yıldız, T. G. (2014). Okul öncesi öz düzenleme ölçeği (OÖDÖ): Türkiye uyarlama çalışması. Eğitim ve Bilim, 39(176), 317-328.

Vohs, K. D., ve Baumeister, R. F. (Eds.). (2016). Handbook of self-regulation: Research, theory, and applications. New York, NY, US: Guilford Publications.

Wentzel, K. R., Barry, C. M., ve Caldwell, K. A. (2004). Friendships in middle school: Influences on motivation and school adjustment. Journal of educational psychology, 96(2), 195. 
Whitebread, D., Coltman, P., Pasternak, D. P., Sangster, C., Grau, V., Bingham, S., ... ve Demetriou, D. (2009). The development of two observational tools for assessing metacognition and selfregulated learning in young children. Metacognition and learning, 4(1), 63-85.

Zimmerman, B. J. (2000). Attaining self-regulation: A social cognitive perspective. In Handbook of selfregulation (pp. 13-39). San Diego, CA, US: Academic Press. 